\title{
Psychometric properties of the influences on planning decision-making in physical education questionnaire (CIPEF)
}

\section{Propiedades psicométricas del cuestionario de las influencias en la planificación de la toma de decisiones en educación física (CIPEF)}

\author{
As propriedades psicométricas do questionário de influências \\ em decisões de planejamento em educação física (CIPEF)
}

Jesús Viciana Ramírez ${ }^{1 *}$, Humberto Blanco Vega ${ }^{2}$ y Daniel Mayorga-Vega ${ }^{1}$

${ }^{1}$ Department of Physical Education and Sport, University of Granada, Spain, ${ }^{2}$ Autonomous University of Chihuahua, Mexico

\begin{abstract}
Introduction. The present study analyzes the psychometric properties of the Influences on the Planning Decision-Making in Physical Education Questionnaire (CIPEF). Literature had contributed instruments for measuring beliefs and value orientations toward Physical Education, but there are no instruments that measure the influence of specific factors on teachers' decision-making when planning Physical Education. Method. The sample consisted of 335 Andalusian teachers (238 men and 97 women, average age $=29.85 \pm 10.94$ years). Exploratory and confirmatory analyses were conducted in order to analyze the factorial structure of the questionnaire. Results. The results showed the viability and adequacy of an eight-factor structure (curriculum standards, preservice training, physical environment, teaching experiences, physical activities experiences, socialization by other teachers, material and equipment, and level of preparation in the subject matters) with adequate fit indices of reliability and validity, and showing strong evidences of stability of the obtained factorial structure. Discussion. This instrument could be used in the analysis of teachers' planning decision-making, which has been studied mainly through qualitative approaches up till now. Further research is recommended in order to corroborate these findings.
\end{abstract}

Keywords: Instrumental study, validity, reliability, factor structure.

Resumen: Introducción. El presente estudio analiza las propiedades psicométricas del cuestionario de Influencias en la planificación de la Educación Física (CIPEF). En la literatura previa se han desarrollado instrumentos de medida de creencias y valores hacia la Educación Física, pero no existen instrumentos que midan la influencia de determinados factores en el momento en que planifican los profesores la Educación Física. Método. La muestra se compuso de 335 profesores andaluces $(238$ hombres y $97 \mathrm{mu}$ jeres, con una edad media de $29.85 \pm 10.94$ ańos). Se realizaron análisis factoriales exploratorio y confirmatorio para analizar la estructura factorial del cuestionario. Resultados. Los resultados mostraron la viabilidad y adecuación de una estructura con ocho factores (currículo nacional, formación inicial, entorno físico del centro, experiencia docente, experiencias en actividad física, socialización del profesor, material e instalaciones, y nivel de preparación en los contenidos de Educación Física) con adecuados índices de ajuste de validez y fiabilidad, mostrando evidencias consistentes de la estructura factorial obtenida. Discusión. Se espera usar el cuestionario en grandes muestras que analicen la toma de decisiones del profesor de cuando planifica la Educación Física, que hasta ahora se había estudiado a través de casos e investigación cualitativa. Se recomiendan futuras investigaciones para constatar estos resultados.

Palabras clave: Estudio instrumental, validez, fiabilidad, estructura factorial. Resumo:. Introdução. O presente estudo analisa as propriedades psicométricas do questionário de Influências sobre a Tomada de Decisáo no planejamento em Educação Física (CIPEF). A literatura contribuiu instrumentos para medir as crenças e orientações de valor em relação á Educação Física, mas não há instrumentos que medem a influência de fatores específicos sobre a tomada de decisão dos professores no planejamento da Educação Física. Método. A amostra foi composta de 335 professores da Andaluzia (238 homens e 97 mulheres, idade média $=29.85 \pm 10.94$ anos). Análises exploratórias e confirmatórias foram realizadas a fim de analisar a estrutura fatorial do questionário. Resultados. Os resultados mostraram a viabilidade e adequaçáo de uma estrutura de oito fatores (padrôes curriculares, formaçáo antes do serviço, ambiente físico, experiências de ensino, experiências nas atividades físicas, socialização por outros professores, materiais e equipamentos e nível de preparação nas matérias) com índices de confiabilidade e validade satisfatórios, e mostrando fortes evidências de estabilidade para a estrutura fatorial obtida. Discussão. Este instrumento poderia ser utilizado na análise do planejamento de tomada de decisão dos professores, que tem sido estudado principalmente através de abordagens qualitativas até agora. Pesquisa adicional é recomendada a fim de corroborar essas descobertas. Palavras-chave: Estudo do instrumento, prazo de validade, confiabilidade, estrutura fatorial.

\section{Introduction}

Education in a scholar setting is a continuous decisional process in which teachers try, through their decisions, to adapt

\footnotetext{
Dirección para correspondencia [Correspodence address]: J. Viciana, Ph. D., Department of Physical Education, University of Granada, Ctra. Alfacar s/n, 18011, Granada (Spain). E-mail jviciana@ugr.es
}

their teaching to the characteristics and necessities that each particular moment and educational setting requests of them. The context around Physical Education (PE) is very special, with physical movements in multiple conditions that depend on a big number of decisions and factors in order to deve- 
lop and perform them in a correct way. These decisions have been studied in PE since Housner and Griffey (1985) verified that planning and interactive decision-making were different between experienced teachers and novice teachers, and consequently the resulting PE was also different. Research in education suggests that teachers do in classroom what they are thinking prior in their decision-making process when planning (Clark \& Yinger, 1987).

The cognitive mediational paradigm has studied, normally from a qualitative point of view, which those decisions are in particular cases, explaining several teachers' principles of procedure in their contexts (Timken \& Mars, 2009). Although qualitative methodology lets us understand and solve particular and practical problems, it does not allow us to analyze large samples in order to know generalized teaching actuations regarding those decisions, nor to identify the factors that influence in this process according to teachers' characteristics or scholar settings. It is necessary to create a measurement instrument that identifies the level of influence of each factor that intervenes within teachers' planning decision-making process.

Up till now, the developed instruments in literature has been focused on teachers' values and beliefs (Ennis \& Chen, 1993; Rimm-Kaufman, Storm, Sawyer, Pianta, \& LaParo, 2006; Witchers \& Travers, 1999; Pratt, Collins, \& JarvisSelinger 2001), which were taken as the conceptual background toward teachers' decisions in teaching PE (Pajares, 1992). However, three considerations need to be mentioned: (a) although these beliefs and value orientations could affect some teachers' decisions, they are also influenced by other factors that affect the decision-making process of the teachers when planning; (b) those value orientations are shaped by some factors that we need to know and how much influence each factor has in redirecting the values and beliefs; and (c) the value orientations and beliefs have the limitation of not being directly related to actions or particular decisions, but they are personal conceptions that configure the personal background that could affect or not the future decisions and PE practices.

Due to all the above mentioned reasons, a valid measurement instrument that identifies the grade of influence of several factors during the teachers' decision-making when planning PE, that is, before making contact with the students in the classroom (e.g., the election and design of objectives in an annual planning in PE) is necessary. This instrument would suppose one more step in the progress to understanding the decision-making process in planning $\mathrm{PE}$ and will give us the opportunity to study wide samples of teachers in different stages of their professional lives (Behets, 2001).

Following the teacher career cycle model of Burke, Christensen, and Fessler (1984) that define that the professional teacher cycles are influenced by external factors, personal dimension, and the institutional environment; and following the PE planning model of Viciana (2002) that divide the factors of influence in planning in two dimensions (personal and contextual), the structural factors of the Planning DecisionMaking in Physical Education Questionnaire (CIPEF, by its acronym in Spanish) were established. Both kinds of factors, personal and professional setting, could guide the knowledge, the decision-making process, and practice in teaching (Carlgren, Handal, \& Vaage, 1994). At the same time, the influence of those factors on planning decision-making in PE were verified in literature, creating a previous conceptual system in order to assure the significance of the factors selected, and to facilitate the design of the items of the CIPEF questionnaire. In total, as shown in Table 1 of theoretical constructs, nine factors were confirmed and taken into account.

Table 1. Theoretical constructs and research evidences with the influence on planning decision-making in Physical Education.

\begin{tabular}{|c|c|}
\hline Factor of influence & Research evidences \\
\hline Curriculum standards & Chen (2006); MacPhail, Tannehill, \& Karp (2013); Polikoff (2013) \\
\hline Preservice training & Contreras, Ruiz, Zagalaz, \& Romero (2002); Curtner-Smith (2007) \\
\hline Physical environment & Aljadeff-Abergel, Ayvazo, \& Eldar (2012); Ehlers, Huberty, \& Beseler (2013) \\
\hline Teaching experiences & Kim \& Housner (2010); Rimm-Kaufman, et al. (2006) \\
\hline Physical activity experiences & Juliusson, Karlsson, \& Gärling, (2005); Klausewitz (2005) \\
\hline Socialization by another teachers & Templin \& Shempp (1989); Silverman \& Ennis (2003) \\
\hline Materials and equipment & $\begin{array}{c}\text { Baumgarten \& Pagnano-Richardson (2010); O’Hara, Reis, Esteves, Bras, \& Branco } \\
\text { (2011); Thomson (2009) }\end{array}$ \\
\hline Educational Center & Ehlers, Huberty, \& Beseler (2013); Heidorn \& Erin (2012) \\
\hline Level of preparation in the subject matters & Bray-Clark \& Bates (2003); Ennis \& Chen (1993) \\
\hline
\end{tabular}


The aim of this study was to construct a valid instrument that measures the level of influence of particular factors on the planning decision-making in PE. This aim entails the consistency of a fitted model of CIPEF factors, the explanation of a wide rage of variance, and a high validity construct after delivered in a varied teachers sample. The results expected after the application of this questionnaire are to deduce conclusions that improve the teacher training in universities, teacher training centers, and in every continuous training program that update the teacher's education. The syllabus of those programs, the contents that we need to focus on, and the intervention of teachers' educators could be improved with a better understanding of the planning decision-making of PE teachers.

\section{Method}

\section{Participants}

The total sample consisted of 335 PE teachers. The participants were 202 pre-service teachers who had realized an annual planning in $\mathrm{PE}(\mathrm{men}=154$, women $=48$, average age $=20.53 \pm 1.70$ years) from three different groups of an Andalusian Faculty of Sport Sciences, and 133 inservice teachers ( 81 belonged to public centers, and 52 to private-public centers) with between one to 34 years of experience from 55 different schools of Granada, Córdoba, Sevilla, and Cádiz $($ men $=84$, women $=49$, average age $=39.18 \pm 8.78$ years $)$. All participants took part voluntarily, and were informed that the confidentiality was guaranteed. After explaining the aim of the study, an informed consent was obtained from all of the participants.

\section{Instrument}

The methodological steps for the development of the instrument were based on Carretero-Dios and Pérez (2005). After reviewing the influential factors of decision-making in planning PE and once the theoretical framework of that influence was confirmed in literature (Table 1), the following steps were conducted:

Initial version and expert evaluation.-The first step consisted of the elaboration of the items depending on the factors that emerged from the theories and literature that the IDP$\mathrm{PE}$ is based on. A total of 68 items were initially designed according to the factors identified theoretically as influential in planning PE (curriculum standards, preservice training, physical environment, teaching experiences, physical activity experiences, socialization by another teachers, material and equipment, and educational center, and level of preparation in the subject matters). Participants rated each item using a Likert scale ranging from 1 (totally disagree) to 6 (totally agree).
The first list of items was presented to a group of experts in order to identify usability problems and its appropriateness in their factor and in the questionnaire. Seven experts took part in this process, six of them were doctors in PE, and three of them were active teachers in PE. Each expert made a qualitative assessment of each item, providing arguments about its appropriateness or not depending on his own criteria and regarding the content validity, which served as subject of interest in the discussion session carried out between all of them. After this assessment process, 55 items were selected for the first version of the CIPEF questionnaire. These items stated the influence of several aspects of each factor on the PE planning that the respondent usually does [e.g., item 13 regarding the influence of the curriculum standards: "In my annual PE planning there is a great influence of the curriculum standards" (translated into English from the original Spanish version, see Table 3)].

Application of a pilot sample.-With the aim of verifying the items and instructions understanding, the usability of the scale, and the rest of the technical aspects of the questionnaire by the respondents, a pilot sample of 75 teachers was initially requested (50 preservice and 25 inservice teachers). Apart from the factors' items, a new item was included at the end of the questionnaire in order to obtain a punctuation that represents the qualitative level of the language understanding by respondents. The result of that item was of 5.29 \pm 0.94 in the scale (one to six), demonstrating a global good understanding of the CIPEF. According to the opinion of some of the teachers, two items that seemed to overlap were eliminated, and a final version of 53 items would be applied to the final sample.

\section{Procedure}

The questionnaires were distributed and collected by two experienced researchers during the second semester of the 201213 academic course. The inservice teachers were contacted and informed in a first session in their educational center, and during a second session were urged to fulfill the questionnaire. The preservice teachers were contacted in each of their classes. The participants were read the instructions and then directed to complete the CIPEF with brief demographics and background information (e.g., age, gender, teacher experience, current physical activity, educational stage). The questionnaire was filled out in approximately 15 minutes and after that all data collected was put into the computer by the main investigator for the posterior analysis.

\section{Data Analyses}

According to Thompson (2004), two stages in the psychometric analysis were made in order to obtain the better proper- 
ties for the definition of CIPEF punctuations: (1) exploratory factor analysis (EFA), and (2) confirmatory factor analysis (CFA).

The first step of the psychometric properties analysis consisted of calculating the discrimination indices for each item. The majority of the 53 items were satisfactory, with discrimination coefficients ranging from .528 for item 1 to .304 for item 28. The items 14, 16, 18, 20, 21, 22, and 53 obtained a discrimination index below .30 (considered as the acceptance criterion), and consequently they were erased from the scale along the subsequent analysis.

An EFA, using the maximum likelihood method, was conducted for the remaining 46 items in order to determine the minimum number of common factors that satisfactorily reproduce the observed correlations between all of the items, according to the Kaiser-Guttman's criterion. In order to guarantee an adequate representation of the variables (items) and after a varimax rotation, only those whose communality (proportion of explained variance by the factor solution) were above .45 were conserved (Costello \& Osborne, 2005). Then, the Cronbach's $\alpha$ coefficient with the aim of estimate the internal consistency for each retained factor as a measurement of their reliability (Elosua \& Zumbo, 2008) was used.

Subsequently, a CFA was conducted with AMOS 16 (Arbuckle, 2007) in order to verify the factor structure of the CIPEF obtained from the previous EFA. The maximum likelihood method was conducted (Thompson, 2004), that is, verifying not only the theoretical model adjustment, but comparing the fit indices of several alternative models in order to select the better one.

In the fit model assessment the chi-squared test, the adjusted goodness of fit index (GFI), the root mean square residual (RMR), the root mean square error of approximation (RMSEA), and the expected cross validation index (ECVI) were used as absolute fit indices. The adjusted goodness of fit index (AGFI), the Tucker-Lewis index (TLI), the normed fit index (NFI) and the comparative fit index (CFI) were used as incremental fit indices. The parsimony normed fit index (PNFI), the parsimony goodness of fit index (PGFI), the chi-squared fit index divided by degrees of freedom (CMIN/DF), and the Akaike information criterion (AIC) were used as parsimony fit indices (Gelabert et al., 2011).

\section{Results}

\section{Exploratory factor analysis}

The significance of the Barlett's test (7788.869; $\mathrm{p}<.001)$ and the KMO index of Káiser-Mayer-Olkin (.811) showed an adequate correlation between the items and a good sample adaptation, respectively. After conducting a varimax rotation, a nine-factor structure (previous elimination of 10 items: 8, $15,17,19,25,26,28,50,51$, and 52 that were not explained enough by the factor solution) was detected. The total set of selected factors explained the $61.08 \%$ of the variance (Tables 2 and 3$)$.

Table 2. Self-values and percentage of explained variance by the retained factors. Exploratory factor analysis.

\begin{tabular}{lccc}
\hline Factor & Self-values & \% of variance & \% accumulated \\
\hline Curriculum standards & 3.31 & 9.19 & 9.19 \\
Preservice training & 3.05 & 8.46 & 17.65 \\
Physical environment & 2.99 & 8.31 & 25.95 \\
Teaching experiences & 2.96 & 8.21 & 34.16 \\
Physical activity experiences & 2.49 & 6.91 & 41.07 \\
Socialization by another teachers & 2.31 & 6.40 & 47.48 \\
Material and equipment & 1.75 & 4.87 & 52.35 \\
Educational center & 1.62 & 4.50 & 56.84 \\
Level of preparation in the subject matters & 1.53 & 4.24 & 61.08 \\
\hline
\end{tabular}


Table 3. Items (see appendix 1) grouped by factor and their alpha coefficients. Exploratory factor analysis.

\begin{tabular}{|c|c|c|c|}
\hline Item & Factor loading & Item & Factor loading \\
\hline \multicolumn{2}{|c|}{ Factor 1: Curriculum standards $(\mathrm{a}=.899)$} & \multicolumn{2}{|c|}{ Factor 6: Socialization by another teachers $(\mathrm{a}=.814)$} \\
\hline Item 13. & .82 & Item 48. & .76 \\
\hline Item 10. & .81 & Item 47. & .73 \\
\hline Item 11. & .80 & Item 46. & .64 \\
\hline Item 12. & .76 & Item 49. & .61 \\
\hline Item 9. & .72 & & \\
\hline \multicolumn{2}{|c|}{ Factor 2: Preservice training $(\mathrm{a}=.879)$} & \multicolumn{2}{|c|}{ Factor 7: Material and equipment $(\mathrm{a}=.791)$} \\
\hline Item 5. & .82 & Item 43. & .74 \\
\hline Item 3. & .72 & Item 44. & .74 \\
\hline Item 4. & .71 & Item 45. & .64 \\
\hline Item 1. & .69 & & \\
\hline Item 2. & .67 & & \\
\hline \multicolumn{2}{|c|}{ Factor 3: Physical environment $(\mathrm{a}=.865)$} & \multicolumn{2}{|c|}{ Factor 8: Educational center $(\mathrm{a}=.750)$} \\
\hline Item 33. & .79 & Item 24. & .85 \\
\hline Item 31. & .78 & Item 23. & .63 \\
\hline Item 29. & .76 & Item 27. & .52 \\
\hline Item 30. & .71 & & \\
\hline Item 32. & .64 & & \\
\hline \multicolumn{2}{|c|}{ Factor 4: Teaching experiences $(\mathrm{a}=.863)$} & \multicolumn{2}{|c|}{ Factor 9: Level of preparation in subject matters $(\mathrm{a}=.851)$} \\
\hline Item 39. & .79 & Item 6. & .85 \\
\hline Item 40. & .75 & Item 7. & .78 \\
\hline Item 41. & .75 & & \\
\hline Item 42. & .71 & & \\
\hline Item 38. & .69 & & \\
\hline \multicolumn{4}{|c|}{ Factor 5: Physical activity experiences $(\mathrm{a}=.848)$} \\
\hline Item 34. & .83 & & \\
\hline Item 35. & .76 & & \\
\hline Item 36. & .73 & & \\
\hline Item 37. & .63 & & \\
\hline
\end{tabular}

\section{Factor reliability (internal consistency)}

The factors that result in the EFA had alphas indices up to .75, which is considered adequate for these kinds of factors, particularly if the reduced number of items is considered (Table 3).

\section{Confirmatory factor analysis}

The factor solution that emerged from the EFA was confirmed by the CFA in order to obtain congeneric models, and at the same time to verify the construct validity of the dimensions and variables studied.

As shown in Table 4, the CFA of 29 items grouped in eight factors denoted a good adjustment between the model and data $(\mathrm{GFI}=.857$; RMSEA $=.061)$ (Jöreskog \& Sörbom, 1993). According to the incremental and parsimony fit indices (Tables 5 and 6) the proposed model was significantly superior to the independent and the nine factor models, and very similar to the saturated model. 
Table 4. Absolute fit measurements for the generated models. Confirmatory factor analysis.

\begin{tabular}{|c|c|c|c|}
\hline \multirow[b]{2}{*}{ Model } & \multicolumn{3}{|l|}{ Fit indices } \\
\hline & GFI & RMR RMSEA & ECVI \\
\hline Independent (36 items) & $6619.082^{*} .345$ & 0.292 .169 & 20.033 \\
\hline Saturated (36 items) & 0 & 0 & 3.988 \\
\hline 9 factors (36 items) & $1345.291^{*} .819$ & 0.140 .062 & 4.513 \\
\hline 9 factors (32 items) & $1021.330^{*} .842$ & 0.133 .061 & 3.495 \\
\hline 8 factors (29 items) & $826.046^{*} .857$ & 0.127 .061 & 2.856 \\
\hline $\begin{array}{l}\text { Note: }{ }^{*} \mathrm{p}<.01 ; \mathrm{ECVI}=\text { expec } \\
\text { index; RMR }=\text { root mean squa } \\
\text { approximation. }\end{array}$ & $\begin{array}{l}\text { ted cross validation in } \\
\text { re residual; } \text { RMSEA = }\end{array}$ & $\begin{array}{l}\text { Idex; GFI = goodne } \\
=\text { root mean square }\end{array}$ & $\begin{array}{l}\text { of fit } \\
\text { ror of }\end{array}$ \\
\hline
\end{tabular}

Table 5. Incremental fit measurements for the generated models. Confirmatory factor analysis.

\begin{tabular}{lllll}
\hline & \multicolumn{4}{l}{ Fit indices } \\
\cline { 2 - 5 } Model & AGFI & TLI & NFI & CFI \\
\hline Independent (36 items) & .308 & 0 & 0 & 0 \\
Saturated (36 items) & & & 1 & 1 \\
9 factors (36 items) & .794 & .863 & .797 & .873 \\
9 factors (32 items) & .842 & .880 & .819 & .890 \\
8 factors (29 items) & .832 & .895 & .840 & .904 \\
\hline
\end{tabular}

Note: AGFI = adjusted goodness of fit index; $\mathrm{CFI}=$ comparative fit index; $\mathrm{NFI}=$ normed fit index; TLI = Tucker-Lewis index

Table 6. Parsimony fit measurements for the generated models. Confirmatory factor analysis.

\begin{tabular}{|c|c|c|c|c|}
\hline \multirow[b]{2}{*}{ Model } & \multicolumn{4}{|c|}{ Fit indices } \\
\hline & PNFI & PGFI & $\mathrm{CMIN} / \mathrm{DF}$ & AIC \\
\hline Independent (36 items) & 0 & .327 & 10.506 & 1590.495 \\
\hline Saturated (36 items) & 0 & & & 182.000 \\
\hline 9 factors (36 items) & .740 & .720 & 2.300 & 1507.291 \\
\hline 9 factors (32 items) & .751 & .725 & 2.245 & 1167.330 \\
\hline 8 factors (29 items) & .767 & .731 & 2.227 & 954.046 \\
\hline
\end{tabular}

Figure 1 shows the measurement model that emerged from the CFA, including the standardized regression coefficients between the items and factors, and the standardized factor saturations (communalities) of each item.
Figure 1. Illustrative model of factors of influence in planning Physical Education

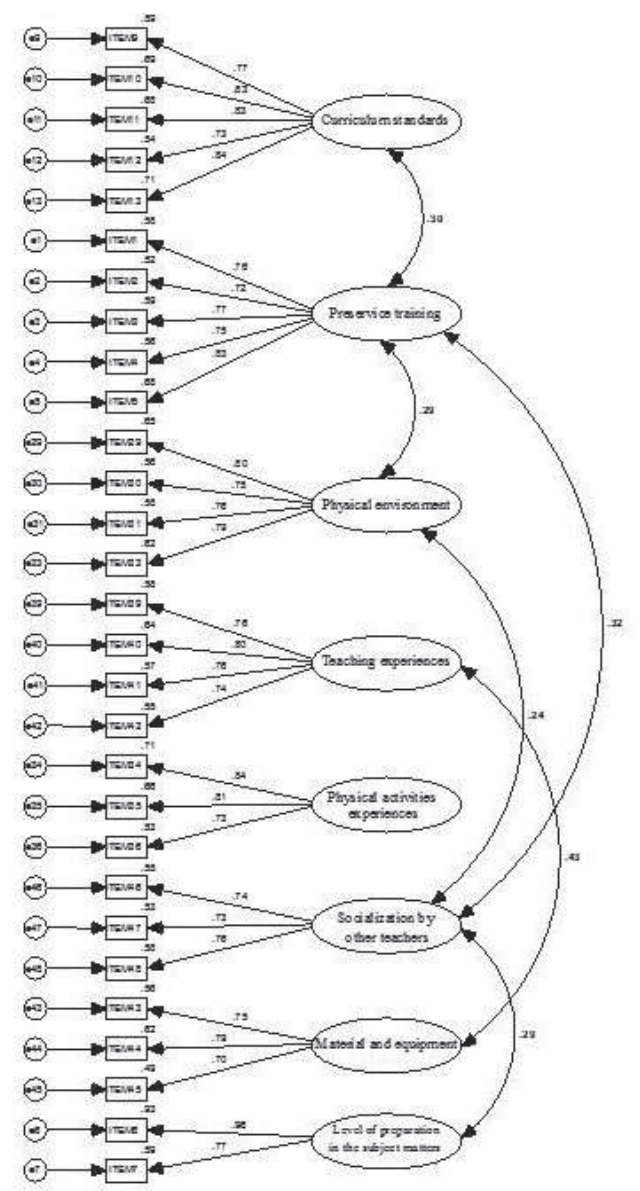

All factors presented high-standardized factor saturations (above .50), except the item 45 that belonged to the material and equipment factor (.49).

The correlations between the preservice factor of influence and the curriculum standards, physical environment, and the socialization by other teachers were positives and statistically significant $(\mathrm{p}<.01)$. The same occurred between the socialization by other teachers with the level of preparation in the subject matters and physical environment, and between the factor of influence of teaching experiences and material and equipment (Figure 1). These results show that the more augmented the perceived influence of some of these factors, the more the others augmented that were related to them.

\section{Discussion}

The IDP-PE has demonstrated a viable and adequate factor structure of 29 items and eight factors, considering the established psychometrics requirements (of fit, reliability, and validity). The factors showed a good internal consistency, particularly if the reduced number of items in each one is consi- 
dered, and in general, these findings suggest the existence of strong evidences of the structural reliability. Therefore, this instrument is valid to measure the influences experienced by teachers when planning the PE.

The identified factors that constitute the sub-scales of the questionnaire are the following:

Factor 1, called "Curriculum standards". This factor was composed of items regarding the influence of the national curriculum guidelines and recommendations in the teachers' decision-making process when planning PE. The alignment of teachers' instructions with national standards has been considered an important factor regarding planning and intervention by most authors in literature (Chen, 2006; MacPhail et al., 2013). Moreover, Polikoff (2013) for instance stated, analyzing a large database of teachers, that instructional alignment is also related to the initial training and experiences in teaching, which were also two important factors included in the CIPEF questionnaire.

Factor 2, called "Preservice training". This factor was composed of items regarding the influence of the curricular practices that teachers experienced during their degree (e.g., methodology, notes, practical sessions, theory and information). The initial training of pre-service teachers has been the most important factor that influences teachers who have not had teaching experiences, and it has been proved that the experiences acquired during the partnership and practices during the career influence in the conception of PE and teaching that teachers had, changing even their previous beliefs (Contreras et al., 2002).

Factor 3, called "Physical environment". This factor was composed of items that take into account the physical environment (urban and natural) surrounding the educational center for planning PE. Planning PE should be influenced by the physical environment that is around the educational center (Aljadeff-Abergel et al., 2012; Ehlers et al., 2013). The use of this space around the center could influence in providing authentic performances for PE students (Newmann, Marks, \& Gamoran, 1995).

Factor 4, called "Teaching experiences". This factor was composed of items that deal with the influence of teachers' teaching experiences (e.g., results obtained in previous planning, intervention experienced in the past, accumulated experiences with students) on the planning of PE.

Factor 5, called "Physical activities experiences". This factor was composed of items regarding the experiences that teachers had in the past and have currently regarding physical activities (e.g., habits, sports modalities, experiences as athletes or physical education students). Experiences in physical activities can impact future decision making regarding planning PE, due to the proven effect that positive experiences have on the decisions people make in the future (Juliusson et al., 2005).
Factor 6, called "Socialization by other teachers". This factor was composed of items that deal with the influence of other teachers on how to plan PE (e.g., shared ideas, team group planning, experiences of other teachers).

Factor 7, called "Material and equipment". This factor was composed of items regarding the influence of the quantity and quality of specific materials of PE and equipment available for planning PE. Among other factors, Baumgarten and Pagnano-Richardson (2010) revealed that material and equipment were crucial elements for planning and learning gymnastics contents in PE, which is according to the factor found in this research regarding the PE planning.

Factor 8, called "Level of preparation in the subject matters". This factor was composed of items that deal with the influence of the self-perception of teachers about their level of preparation in the subject matters, their knowledge and level of expertise. Chen (2009), validated the Achieving the National Association for Sport and Physical Education (NASPE) Standards Inventory (ANSI), that assesses pre-service PE teachers' perception of achieving the NASPE beginning teachers standards, confirming that the knowledge, the disposition, and the skills they have around PE were important factors in planning and intervention in PE. These results verify the importance of the level of teachers' preparation in planning the PE subject.

The relationship between the sub-scales confirms that planning PE is a complex task that is influenced by multiple factors (Viciana, 2002). Teachers plan PE during a decisionmaking process that is different for each of them (depending on their experience, age, etc.), and detecting those factors is crucial for identifying and recommending new guidelines for pre-service and in-service phases of teacher training.

According to Gelabert et al. (2011), the factor validity of an instrument needs to be demonstrated with a great variety of samples. Therefore, further studies need to be carried out in the future in order to complete the total availability of the CIPEF questionnaire.

\section{Practical applications}

As mentioned in the introduction section, it is important to emphasize humbly, that the validation of a questionnaire as carried out in this study represents an important contribution for scientists and will have practical repercussions: (a) to identify several profiles of teachers when planning. Each teacher's professional stage has a particular incidence of factors when planning their PE [e.g., novice teachers, with a short teaching experience, could be affected mainly by the pre-service training (Van der Berg, 2002)]. In fact, Downey, Steffy, English, Frase and Poston (2004) stated that the effective professional development for each professional stage should be different between them in order to be effective. Therefore, knowing 
the main factors of influence in each moment is crucial in order to make adequate decisions by teachers' educators; (b) to detect possible cultural differences in the planning decisionmaking process by teachers from different countries (Babville, Derosiers, \& Gener-Violet, 2002); and (c) to assess the changes produced on a group of teachers by an intervention program or educational reforms (Matanin \& Collier, 2003). Many educational reforms have been carried out in the last years in many countries that demand new methodological strategies and interventions (and consequently new decisions and annual planning in PE). Thus, it is important to have an instrument that allows us to understand deeply this decisional process and lets us intervene in the universities and educational centers reorienting the teachers' training and the PE matters.

Acknowledgments: We thank Aliisa Hatten for the English revision. Daniel Mayorga-Vega is supported by a grant from the Spanish Ministry of Education, Culture and Sport (AP2010-5905).

\section{References}

1. Aljadeff-Abergel, E., Ayvazo, S., \& Eldar, E. (2012). Social skills training in natural play settings: Educating through the physical theory to practice. Intervention in School and Clinic, 48(2), 78-86.

2. Arbuckle, J. R. (2007). AMOS users guide version 16.0. Chicago, IL: Marketing Department, SPSS Incorporated.

3. Babville, D., Derosiers, P., \& Gener-Violet, Y. (2002). Comparison of value orientations of Quebec and American teachers: A cultural difference? Teaching and Teacher Education, 18, 469-482.

4. Baumgarten, S., \& Pagnano-Richardson, K. (2010). Educational gymnastics: Enhancing children's physical literacy. Journal of Physical Education, Recreation \& Dance, 81(4), 18-25.

5. Behets, D. (2001). Value orientations of physical education preservice and inservice teachers. Journal of Teaching in Physical Education, 20, 144-154.

6. Bray-Clark, N., \& Bates, R. (2003). Self-efficacy beliefs and teacher effectiveness: Implications for professional development. The Professional Educator, 16(1), 13-22.

7. Burke, P. J., Christensen, J. C., \& Fessler, R. (1984). Teacher career stages: implications for staff development. Indiana: Phi Delta Kappa Educational Foundation.

8. Carlgren, I., Handal, G., \& Vaage, S. (Eds.). (1994) Teachers' Minds and Actions: Research on Teachers' Thinking and Practice. London: Falmer Press.

9. Carretero-Dios, H., \& Pérez, C. (2005). Normas para el desarrollo y revisión de estudios instrumentales [Norms for the development and revision of instrumental studies]. International Journal of Clinical and Health Psychology, 5(3), 521-551.

10. Chen, W. (2006). Teachers' Knowledge about and Views of the National Standards For Physical Education. Journal of Teaching in Physical Education, 25, 120-142.

11. Chen, W. (2009). Confirmatory factor analysis of achieving the beginning teacher standards inventory. Educational Research and Evaluation: An International Journal on Theory and Practice, 15(3), 285-304.

12. Clark, C. M., \& Yinger, R. (1987). Teacher planning. In J. Calderhead (Ed.), Exploring teachers' thinking (pp. 84-103). London: McKay.

13. Contreras, O., Ruiz, L., Zagalaz, M. L., \& Romero, S. (2002). Creencias en la formación del profesorado de Educación Física [Beliefs in physical education teacher training]. Revista Interuniversitaria de Formación del Profesorado, 45, 131-149.

14. Costello, A. B., \& Osborne, J. W. (2005). Best practices in exploratory factor analysis: four recommendations for getting the most from your analysis. Practical Assessment, Research and Evaluation, 10(7), 1-9.

15. Curtner-Smith, M. D. (2007). The impact of a critically oriented physical education teacher education course on preservice classroom teachers. Journal of Teaching in Physical Education, 26, 35-56.

16. Downey, C., Steffy, B., English, F., Frase, L., \& Poston, W. Jr. (2004). The three-minute classroom walk-through. Thousand Oaks: Corwin Press.
17. Ehlers, D. K., Huberty, J. L., \& Beseler, C. L. (2013). Is School community readiness related to physical activity before and after the ready for recess intervention? Health Education Research, 28(2), 192-204.

18. Elosua, P., \& Zumbo, B. D. (2008). Coeficientes de fiabilidad para escalas de respuesta categórica ordenadas. Psicothema, 20(4), 896-901.

19. Ennis, C. D., \& Chen, A. (1993). Domain specifications and content representativeness of the revised value orientation inventory. Research Quarterly for Exercise and Sport, 64(4), 436-446.

20. Gelabert, E., García-Esteve, L., Martín-Santos, R., Gutiérrez, F., Torres, A., \& Subirà, S. (2011). Psychometric properties of the Spanish version of the Frost Multidimensional Perfectionism Scale in women. Psicothema, 23(1), 133-139.

21. Heidorn, B., \& Centeio, E. (2012). The director of physical activity and staff involvement. Journal of Physical Education, Recreation \& Dance, 83(7), 13-19.

22. Housner, L. D., \& Griffey, D. C. (1985). Teacher cognition: Differences in planning and interactive decision-making between experienced and inexperienced teachers. Research Quarterly for Exercise and Sport, 56, 45-53.

23. Jöreskog, K. G., \& Sörbom, D. (1993). LISREL8: Structural equation modeling with the SIMPLIS command language. Hillsdale, NJ: Erlbaum.

24. Juliusson, E. A., Karlsson, N., \& Gärling, T. (2005). Weighing the past and the future in decision-making. European Journal of Cognitive Psychology, 17(4), 561-575.

25. Kim, H., \& Housner, L. D. (2010). The influence of class size on the planning, decision-making, concerns, and instructional behaviors of experienced and inexperienced teachers. International Journal of Applied Sports Sciences, 22(2), 77-95.

26. Klausewitz, S. K. (2005). How prior life experiences influence teaching: multiple case studies of mature-age elementary student teachers. Electronic doctoral dissertations for umass amherst. Retrieved from http://scholarworks.umass.edu/dissertations/aai3179892

27. MacPhail, A., Tannehill, D., \& Karp, G.G. (2013). Preparing Physical Education preservice teachers to design instructionally aligned lessons through constructivist pedagogical practices. Teaching and Teacher Education, 33, 100-112.

28. Matanin, M., \& Collier, C. (2003). Longitudinal analysis of preservice teachers' beliefs about teaching physical education. Journal of Teaching in Physical Education, 22, 153-168.

29. Newmann, F. M., Marks, H. M., \& Gamoran, A. (1995). Authentic Pedagogy: Standards that boost student performance. Issues in Restructuring Schools, 8, 1-12.

30. O’Hara, K., Reis, P., Esteves, D., Bras, R., \& Branco, L. (2011). Science, sport and technology. A contribution to educational challenges. Electronic Journal of e-Learning, 9(1), 87-97.

31. Pajares, M. F. (1992). Teachers' beliefs and educational research: 
cleaning up a messy construct. Review of Educational Research, 62(3), 307-333.

32. Polikoff, M. S. (2013). Teacher education, experience, and the practice of aligned instruction. Journal of Teacher Education, 64(3), 212225.

33. Pratt, D., Collins, J. B., \& Jarvis-Selinger, S.A. (2001). Development and use of the Teaching Perspectives Inventory (TPI). Paper presented at the annual meeting of The American Educational Research Association, Washington, April.

34. Rimm-Kaufman, S. E., Storm, M. D., Sawyer, B. E., Pianta, R. C., \& LaParo, K. M. (2006). The Teacher Belief Q-Sort: A measure of teachers' priorities in relation to disciplinary practices, teaching practices, and beliefs about children. Journal of School Psychology, 44, 141-165.

35. Silverman, S. J., \& Ennis, C. D. (2003). Student learning in physical education. Champaign, IL: Human Kinetics.
36. Templin, T. J., \& Schempp, P. G. (1989). Socialization into physical education. Indianápolis, IN: Benchmark Press.

37. Thompson, B. (2004). Exploratory and Confirmatory Factor Analysis. Understanding concepts and applications. Washington, D.C.: American Psychological Association.

38. Thomson, W. C. (2009). Stretching your budget: Notes on working with sporting goods dealers. Strategies: A Journal for Physical and Sport Educators, 23(1), 20-23.

39. Timken, G., \& Mars, H. (2009). The effect of case methods on preservice physical education teachers' value orientations. Physical Education and Sport Pedagogy, 14(2), 169-187.

40. Van den Berg, R. (2002). Teachers' meaning regarding educational practice. Review of Educational Research, 72(4), 577-625.

41. Viciana, J. (2002). Planificar la Educación Física. [Planning in Physical Education]. Barcelona: Inde.

\section{APPENDIX 1 CUESTIONARIO DE INFLUENCIA EN LA PLANIFICACIÓN DE LA EDUCACIÓN FÍSICA (CIPEF)}

El presente cuestionario trata de recabar su opinión acerca de cómo planifica y cuáles son los factores que más le condicionan para hacerlo. A continuación le exponemos una serie de afirmaciones para que usted seńale en una escala de 1 a 6 el grado de acuerdo que posee de cada una de ellas. Todos los ítems representan influencias que pueden o no afectarle a usted cuando planifica la EF. Marcar valores bajos de la escala no supone negar dicha influencia, sino que en su planificación de la EF no ha influido o ha influido poco. Conteste con seriedad y tome el tiempo oportuno para ello. Pregunte cualquier aspecto que le resulte extrańo o incomprensible para responder así con mayor objetividad. Le garantizamos que sus respuestas serán confidenciales para que pueda responder con total libertad y sinceridad.

Rodee la respuesta que proceda

Edad: _____ Sexo: Hombre/Mujer Etapa: EPO/ESO Formación: Magisterio EF/Magist. otro/Licenciatura EF/Lic. OtroCentro: Rural/Urbano Tipo: Privado/Privado-concertado/Público Ańos de experiencia docente:

\begin{tabular}{|c|c|}
\hline $\begin{array}{r}\text { Totalmente } \\
\text { Desacuer }\end{array}$ & $\begin{array}{ll}\text { en } & \text { Totalmente } \\
\text { do } & \text { de acuerdo } \\
\end{array}$ \\
\hline \multicolumn{2}{|l|}{ Influencia de la Formación Inicial } \\
\hline 1. La información que recibí en mi facultad me influye a la hora de planificar la EF & 123456 \\
\hline $\begin{array}{l}\text { 2. Las tendencias que promulgaban los profesores cuando estudiaba la carrera condiciona actualmente mi planifica- } \\
\text { ción de la EF }\end{array}$ & 123456 \\
\hline 3. Utilizo los materiales y apuntes de la carrera para planificar la EF & 123456 \\
\hline 4. La metodología que usaban mis profesores en la carrera me influye a la hora de planificar mi intervención en la EF & 123456 \\
\hline 5. Las experiencias formativas que tuve como estudiante en la facultad me influyen a la hora de planificar la EF & 123456 \\
\hline \multicolumn{2}{|l|}{ Influencia del nivel de preparación en los diferentes contenidos } \\
\hline 6. Si tengo más formación en un contenido tiendo a planificarlo y usarlo más en mis clases de EF & 123456 \\
\hline $\begin{array}{l}\text { 7. Cuantos más conocimientos tengo sobre un contenido determinado más tendencia tengo a usarlo en mi planifica- } \\
\text { ción de la EF }\end{array}$ & 123456 \\
\hline \multicolumn{2}{|l|}{ Influencia del currículo nacional (normativa del BOE) } \\
\hline 9. El currículo oficial es muy influyente en la planificación que realizo de la EF & 123456 \\
\hline 10. Las indicaciones del currículo nacional son para mí prioritarias para planificar la EF & 123456 \\
\hline $\begin{array}{l}\text { 11. La planificación de la EF la realizo basándome fundamentalmente en el currículo oficial para la etapa (nivel) en } \\
\text { que estoy trabajando }\end{array}$ & 123456 \\
\hline 12. Las indicaciones oficiales del currículo normativo marcan mi programación y por tanto mis clases de EF & 123456 \\
\hline
\end{tabular}


13. En mi programación de la EF hay una gran influencia del currículo oficial

\section{Influencia del entorno físico}

29. Cuando planifico la EF suelo buscar aplicaciones en el entorno cercano del centro donde trabajo 123456

30. Las características de la ciudad donde trabajo influyen a la hora de planificar la EF 123456

31. Mi planificación de la EF siempre contempla el entorno disponible para planificar los contenidos y cómo usarlo

123456

33. En mi planificación de la EF tengo muy en cuenta el entorno urbano y sus posibilidades

123456

\section{Influencia de las experiencias en la práctica de $\mathrm{AF}$}

34. La actividad física que realizo hace que planifique la EF de una forma diferent

35. El deporte que practico me influye en la planificación que hago de la EF

123456

36. Mis hábitos de práctica de actividad física me influyen para planificar la EF

123456

\section{Influencia de las experiencias docentes}

39. Los resultados de mi docencia me sirven para planificar la EF de siguientes cursos

40. La efectividad de mi intervención con los alumnos es clave para planificar la EF del año siguiente

41. Los éxitos y los fracasos que tengo durante mi enseńanza de la EF me orientan para planificar la EF en años sucesivos

42. Las experiencias que voy acumulando en mis clases me influyen actualmente a la hora de planificar la EF

123456

\section{Influencia de los materiales e instalaciones}

\begin{tabular}{ll}
\hline 43. Normalmente planifico la EF según los materiales didácticos que tengo disponibles & 123456 \\
\hline $\begin{array}{l}\text { 44. Las características de las instalaciones deportivas que tengo disponibles en el centro son fundamentales en mi } \\
\text { planificación de la EF }\end{array}$ & 123456
\end{tabular}
planificación de la EF

45. Tener o no un tipo de materiales determinado me hace planificar la EF adaptada a ellos 123456

\section{Influencia de otros profesores de EF}

\begin{tabular}{ll}
\hline 46. Las experiencias de otros compañeros de profesión me ayudan a planificar la EF & 123456 \\
\hline 47. Tengo en cuenta las opiniones de otros profesores de EF para planificar mis clases de EF & 123456 \\
\hline 48. Suelo compartir mis ideas sobre cómo plantear la EF en mis clases con otros compañeros para planificar & 123456
\end{tabular}

Nota: La numeración de los ítems se corresponde con la original, por ello, algunos números de orden de ítems no aparecen (al haber sido eliminados en el proceso de validación). Esta numeración corresponde con la que aparece en la figura 1 para la comprensión global del artículo. 